\title{
Abuja: Nigeria's Spatial Economic Turmoil and Urban Development Disarray
}

\author{
Bons N. Obiadi1, A. M. Ezezue1, Peter Umo Uduak ${ }^{2}$ \\ ${ }^{1}$ Department of Architecture, Faculty of Environmental Sciences, Nnamdi Azikiwe University, Awka, Nigeria \\ ${ }^{2}$ Department of Architecture, Faculty of Environmental Studies, University of Uyo, Akwa, Nigeria \\ Email: bonsobi@yahoo.com
}

How to cite this paper: Obiadi, B. N., Ezezue, A. M., \& Uduak, P. U. (2019). Abuja: Nigeria's Spatial Economic Turmoil and Urban Development Disarray. Current Urban Studies, 7, 371-398.

https://doi.org/10.4236/cus.2019.73019

Received: July 20, 2019

Accepted: September 16, 2019

Published: September 19, 2019

Copyright $\odot 2019$ by author(s) and Scientific Research Publishing Inc. This work is licensed under the Creative Commons Attribution International License (CC BY 4.0).

http://creativecommons.org/licenses/by/4.0/

\begin{abstract}
Abuja, Nigeria as a befitting Federal Capital Territory, centrally located, without the defects of Lagos was spawned in 1975. The site was chosen for its location at the center of the nation, its small population and for political reasons. In the process, a Master Plan was developed. However, subsequent governments in Abuja abused the integrity of the Master Plan and that resulted in Abuja urbanization and housing inadequacy. The most vulnerable is that, the urban poor had to arrange, on their own, where to live and that resulted in shanty settlements, hence "spatial dialectics," informal volumetric and unvolumetric combination now called the "spatial house", "open house" or "house without limit". This work aimed to document the problems associated with inappropriate implementation of the Abuja Master Plan that resulted in Abuja urbanization and housing inadequacy and proffers solutions to the Abuja housing problems. The authors adopted content based analysis, qualitative research method that involved data from primary and secondary sources. The Abuja Master Plan was elaborated to put in place, sustainable urban spatial environment for all groups and activities to be carried out in the Capital Territory. It provided low-income settlement areas, to be built by the government and occupied by the public servants; the private sector servants did not appear to be properly provided for. The current Abuja housing settlements are not integrated. There is need for the formal, informal settlements and the Abuja urban actors to be talking and link with the Central City infrastructure to create a diverse economy and economic empowerment of all.
\end{abstract}

\section{Keywords}

Spatial, Urbanization, Economy, Housing, Population

\section{Introduction}

The end of the Nigerian civil war in 1970 brought economic rush to urban areas 
in Nigeria and especially, Lagos. The rush to the urban areas stampeded urbanization and according to Okonkwo (2013), in the contemporary Nigerian situation, urbanization is an unstoppable phenomenon and is not a recent phenomenon in the history of Nigeria.

This phenomenon according to Obiadi (2018) citing Okonkwo (2013), was nation-wide, affecting mostly state capital cities such as Enugu, Lagos, Jos, Ibadan, etc. New employment opportunities became available with the emergence of many industrial units in these urban centers. In addition, the creation of 19 states, each with its own capital city, stimulated a drift of population to these capitals with the associated demand for housing both for official and for private residential uses. These developments produced great pressure on the sizes of urban centers in Nigeria.

Urbanization which occurs without adequate industrialization, sufficient formal employment or secure wages, has condemned burgeoning urban populations in the Third World to poor-quality housing. The problem has been compounded by a lack of government funds for housing subsidies, by inflated land prices boosted by housing needs and speculation, and by real-estate profiteering on the part of the upper and middle classes. The operation of the class structure of Third World cities nowhere is more geographical explicit than in the composition and working of the housing market. Only the small upper and middle classes in Third World cities have income, job security and credit worthiness to purchase or rent houses in properly surveyed, serviced and legally conveyed developments (Dickenson et al., 1983). Urbanization in Lagos resulted from Lagos, not having the capacity to accommodate the population growth and housing inadequacy.

In May 1967, Lagos emerged as both the Federal Capital of Nigeria as well as the capital of Lagos State with the creation of states and the continued retention of Lagos as the Federal Capital was seriously questioned. The dual role became a source of embarrassing political and administrative complications with the result of that, Lagos became not only unlivable and unserviceable, but also ungovernmeble (Nwafor, 1980; Okonkwo, 2006).

Nwafor (1980) stated that, as a result of the peripheral location of Lagos, the city has tended to acquire a "regional" rather than a truly national capital where provincialism is stronger than the feeling of the nation's unity. In Nigeria where there is an urgent need to create a national identity and preserve the country as a political unit, the "created capital" should be so located as to convey "a feeling of locational and functional neutrality" (Nwafor (1980), citing Stephenson, 1970, Okonkwo, 2006).

The need to transfer the capital of Nigeria from Lagos to Abuja, came as a result of the former nation's capital, Lagos, being overcrowded, congested and had no lands for expansion. Olaitan (2004) indicated that, the concept of Abuja as a befitting Federal Capital Territory, centrally located and without the defects of Lagos was spawned in 1975. According to Olaitan (2004), the Federal Capital City is located on the Gwagwa Plains in the northeastern quadrant of the Federal 
Capital Territory. It is bounded by the Abuja Hills to the east and the Zango-Kuku Hills to the south. The site for the Federal Capital City was chosen for its location at the center of the nation, its moderate climate, small population and also for political reasons. To accomplish the goal of relocating the Federal Capital to an area, geographically central to Nigeria and with relative equal accessibility to all parts of the nation, about 845 villages were displaced to make way for the Federal Capital Territory, FCT (Olaitan, 2004). The government wanted an area, free of all encumbrances, a principle of "equal citizenship" within the territory where no one can "claim any special privilege" of "indigeneity" as was the case with Lagos (Jibril, 2006; Okonkwo, 2006).

It wanted all the existing population to be moved out of the territory. That was why it authorized not only a census of economic assets of all the inhabitants of the territory but also undertook to pay compensation for all their owners outside of the territory (Jibril, 2006, citing Mabogunje in Ayileka \& Kalgo, 2001).

In the process of establishing a befitting new nation's capital, a Master Plan of the Abuja Federal Capital Territory was designed. The resultant Master Plan was prepared such that land use, infrastructure, housing, transportation, recreation, economic and social services are coordinated and inter-related, Olaitan (2004), citing Abba (2003). Successive governments in Abuja have neglected these principles. As such, a series of distortions to the concept, direction and implementation of the master plan are prevalent today (Olaitan, 2004).

As a result of these changes in the Abuja Master Plan and policy inconsistencies, the Abuja Central City designed to be a model city is not sustainable. It is divided between success and failures, rich and poor. It has potentials to flourish, but in most part, impoovished. The Central City is characterized by urban dialectics, dualistic living and infiltration of the formal settlement areas by informal settlers because of provision of services to the inhabitants of the formal settlement areas. There exist, a clear disparity in the socio-economic base of the two settlements yet, they co-exist. The two settlements co-existing within the formal settlement areas of the Central City are not integrated yet, because of nearness to their jobs and survival, the informal settlers infiltrating the formal settlement areas characterized as the urban poor, find their ways into the formal settlement areas of the Central City. In order to provide services and earn their living, the urban poor, through self-efforts, provide their shelters on government vacant lands, abandoned buildings and on city side-walks (Plate 1). The informal settlement areas within the Central City of Abuja are not integrated into the Central City infrastructure and that is one of the major challenges of the city as a result, promoting urban poor growth that resulted in squatter settlements.

A typical space becomes the shelter/house and the house becomes the space (for most of these people who are security guards, their relations and friends) in the case of urban poor and urban poor housing in Abuja. In most cases, these spaces are without spatially distributed objects yet, they are side by side with formal settlements without proper links and visually acceptable urban objects, 


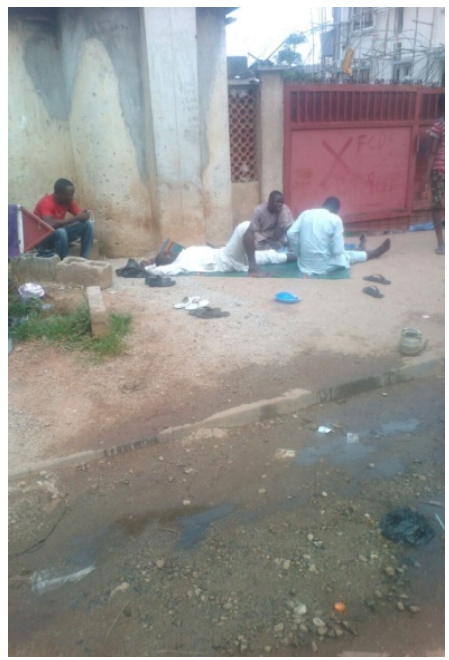

Source: Obiadi (June 2016)

Plate 1. Abuja's public space (housing/shelter).

elements and qualities. The nature of the socioeconomic complexity of these informal spaces, which analysis is shown in this work, constitute a strongly identifiable character which is in this work christened Spatial Housing. It is so termed because of the assumption of the public/open space into the provision of the basic (spatial) socioeconomic, psychological, shelter, etc. needs of the urban poor.

This phenomenon is different from those of the destitutes/homeless people in the city. The informal inhabitants are more or less fixed in location (even though improper location) and actively dependent on the socioeconomic activities of the urban economy. To that effect, Abuja urbanization is growing more than the area's urban development vis-à-vis housing and economic resources. In the formal sense, spaces can be defined and differentiated, however same cannot be said in the informal, hence "spatial dialectics". Within the space is the spatial housing characterized by informal volumetric and unvolumetric combination now called the "spatial house", "open house" or "house without limit" (Plate 1).

\section{Challenges of Abuja}

Adeponle (2013) observed that Abuja city is growing faster (13\%) than the provisions of its Master Plan. It is fast turning into an environmental embarrassment, with developments springing up in gross isolation of zoning and other planning codes. Abuja, which was supposed to be an epitome of beauty and an enlightened vision of city development, has suffered over the years from unnecessary distortions in the implementation of its Master Plan.

Abuja faced the challenges like all the new nation's capital; relocation, resettlement and development. Development was taken to areas which hitherto were not only generally sparsely populated but also contributed quite little to the national economies of each country. Most great cities around the world enjoy a substantial amount of patronage and reputation by virtue of two major factors, 
among numerous others, namely: "the visual amenity", defined as the general attractiveness of the environment, and "the cultural content" of the city, which is a property of the city capable of projecting significant aspects of the lifestyle of its inhabitants to the international community (Uloko, 2005). Madrid, the capital of Spain, is situated at an altitude of 2148 feet near the geometrical center of the Peninsula on an arid plateau bounded in the northwest by the Sierra de Guadarrama. The place is first mentioned in connection with one of the periodical incursions of the kings of Leon into the territory of the Arabs. In the year 939 Ramiro II, King of Leon, advanced towards a place called "Magerit"-an advanced strongpoint of the Arabs defending their Kingdom of Toledo-destroyed its walls, and abandoned it. This fortified settlement which was situated in a strategically favourable position was the origin of Madrid (Gutkind, 1967).

One way of expressing national goals has been through the establishment of new towns; as capitals for countries which had little urban development or where the colonial capital was poorly placed for national needs, and also as centers for industry. Nouakchott and Gaborone were developed as capitals of Mauritania and Botswana, respectively. During the colonial era, both countries were ruled from outside their national territory (from St. Louis in Senegal and Mafeking in South Africa), so new capitals had to be built at independence. Both of these new capitals are in peripheral locations, but Gaborone is accessible to most of the country's ethnic groups. Nouakchott's role as a port is similar to that of many colonial capitals, though it must complete with the port at Nouadhibou, which was expanded to handle mineral exports. Although the pastoral Mauritanians are ambivalent about urban life, Nouakchott has become a political, administrative, cultural, and economic center of which they can be proud. Gaborone is smaller, reflecting the size of Botswana, but has proved to be a strong drawing-point for the country's literate (Pitte, 1977; Bell, 1981).

Malawi, Nigeria, and Tanzania have officially moved their capitals to Lilongwe, Abuja, and Dodoma, respectively. There are plans to move the Ivory Coasts capital from Abidjan to Yamoussoukro. In all four cases, a central location has been politically expedient, but the costs of the move have been a considerable economic burden to the country as a whole; the development of other areas has inevitably suffered. Arguments for a move are often phrased in terms of regional development, limiting the growth of the present metropolis and more equal accessibility to all sectors of the population, especially in cases where the colonial capital was monopolized by one ethnic group. There is also a desire to move away from colonial memories and constraints to a new town which can be given a more African structure. However, the old capital's location and infrastructure may make it more attractive to industry and commerce than a more central location, as the old centers had under colonial rule been trade centers in produce exports (Peil \& Sada, 1984).

The move from Zomba to Lilongwe was designed to promote development in the agriculturally rich central region of Malawi. Zomba was too near the com- 
mercial capital and primate city of Blantyre and was an inadequate site for future growth. But Lilongwe is also near President Banda's birthplace, and the development of a new capital may be seen as a permanent memorial to Malawi's first president. The project absorbed at least $15 \%$ of development expenditure during the 1970 s, far more than the $£ 30$ million estimated. The city was then largely administrative, having attracted very little commerce or industry from Blantyre (Mlia, 1975; Potts, 1984). The Ivorian situation is similar. Yamoussoukro is President Houphouet-Boigny's birthplace, and extensive development of the village provided the impetus for making it the capital.

Dodoma was proposed as a capital for Tanganyika as early as 1915 because of its centrality and climate, but, as in Malawi, the cost of a transfer was more than colonial authorities were willing to bear. The socialist ideology of the Nyerere government proved more persuasive. With the expansion of the port to handle both Tanzanian and Zambian cargoes and large-scale migration, pressure on urban facilities in Dar-es-Salaam increased the rate of urban decay. The move to Dodoma was an attempt to reduce urbanization in one part of the country and develop a new major urban node which will contribute substantially to a previously under-serviced rural area. Other than cost, the main problem is an adequate water supply. The new city was designed to encourage contacts between its residential communities and between the city and all parts of the country. The target population was 350,000 by the end of 1999 . Both Dodoma and Lilongwe were already moderately sized towns at the time they were chosen, but transformation into a capital city had meant destruction as well as growth to satisfy the planners' goals (Hoyle, 1978, 1979).

Abuja, on the other hand, is a completely new town, on a site which had very few residents and thus could not be associated with any Nigerian ethnic group. Oil money made it possible to spend millions of naira to speed the building of Abuja, but the full transfer of the seat of government from Lagos only took place in 1991. The new capital is intended to serve "as symbol of Nigeria's aspiration for unity and greatness" as a central, neutral and healthful place with plenty of room for urban development (Abuja Master Plan, 1979: p. 27).

Okonkwo (2006), in an article, "the Building of a New Capital and its Local Communities: Abuja Federal Capital City on Focus," made a detailed and extensive study of the reasons for the development of New Capitals and the study of Abuja FCT. It is out of his explanations that the present authors extracted greater part of what is presented in this section, as it were an account of Abuja's geographic information and development objectives. The geography of Nigeria is characterized by three large Plateau areas divided from one another by the troughs of the Niger and Benue Rivers. Along the seacoast stretches an alluvial plain averaging about 100 miles in width. This alluvial plain bulges out into the Atlantic Ocean where the Niger delta with its intricate pattern of watercourses penetrates it. The characteristic vegetation of the coastal plain is a dense tropical rain forest. This is replaced by various types of savanna vegetation as the Plateau 
uplands rise from the coastal plain. Moving north, the climate becomes drier until at the north boundary of the country it becomes nearly desert. The site selected for Abuja Federal Capital Territory (FCT) and defined in the 1976 Federal Capital Territory decree is an 8000 square-kilometer area south of Abuja (the town which lost its name to the New Capital City and is now called Suleja) surrounded by Niger, Kaduna, Plateau, and Kwara States. The Federal Capital Territory (FCT) is central to Nigeria lying just above the hot and humid lowlands of the Niger/Benue trough but below the drier parts of the Niger and Benue rivers. The Jema's platform, a continuation of the Jos Plateau, extends well into the middle of the Territory.

Within this general geographic context, the FCT itself consists of a tilted plain rising from elevation 300 feet in the southwest corner to above 2000 feet at the northeast corner. Rising out of this tilted plain are numerous rocky knobs and inselbergs and several ranges of low mountains. This kind of landscape also characterizes large areas of the region surrounding the FCT. In the areas overlooking the Niger-Benue lowlands the hills change to flat-topped laterite capped mesas. Based on the various Federal Surveys mappings of the FCT, there were known to be between 500 and 600 settlements and villages located within the FCT. Generally, these settlements were scattered relatively evenly throughout the four major plains areas of the Territory. The few concentrations of settlements that did exist occurred either along the major existing road-ways or along the major streams and rivers flowing through the Territory. Although approximately 120 (or 22 percent) of the settlements were directly served by some type of roadway, many of the remaining villages were in extremely remote locations which were then connected to surrounding settlements only by footpaths.

Reconnaissance of the FCT suggested that many of these settlements were very small, some under 100 person's total population. The former Kwara State portion of the FCT, encompassing less than one twentieth of the entire site contained over 15,000 people. The area for the FCC's first phase of development contained approximately 11,000 people. Based on existing data, the entire FCT may have had a population of over 300,000 or an average population density of 0.3 to 0.4 persons per hectare.

At commencement of building of the new capital, very few of the then existing settlements had some type of health, education, or welfare services. Based on information taken from Federal Survey maps of the FCT, the following 13 settlements within or immediately adjacent to the FCT were known to have community facilities or services: Wuse (school); Karu (district headquarters, school, market); Garui (school); Bwari (market); Garki (school, dispensary); Garki (school); Izom (school, market); Abriza (general hospital, pottery training center, school); Gamu (church); Dafia (school); Dangara (school); Abaji (school, church); and Masaka (school, market). Gwagwalada, though known to be one of the larger settlements in the Territory, was not indicated by Federal Surveys as having any facilities. 
Representing only about 2 percent of the total number of these settlements in the FCT, most of these villages were located along the major roads that cross the Territory. Assuming that 5 kilometers are the maximum distance people might be expected to travel to these villages with services, only about 80 settlements (or 15 percent of the total number) fell within this accessibility radius. If 10 kilometers were assumed to be the accessibility perimeter, then approximately 186 settlements (or 34 percent of the total number) might be considered to be served by existing facilities. The FCT was accessed by roads generally limited to the central sections along the two major road corridors. Areas outside these corridors were served only by several dirt tracks running from larger villages. About 1976, there were 259 settlements within 5 kilometers of existing roadway, or approximately 47 percent of the total number of settlements Okonkwo (2006).

The design concept and physical development of the new capitals have been underpinned by the theory and principles of "garden city" by Ebenezer Howard (1898) which influenced the building of Letchworth in 1902 and Welwyn in 1920 as new towns, dealing with urban poverty, inadequacy of housing and spatial integration.

Adiukwu (2014), in his Prospects and Challenges of Informal Settlements and Urban Upgrading in Abuja, indicated that, poverty has a social dimension (poor quality of housing and the living environment, i.e. lack of access to basic services like clean water, health care, education etc.). Abuja is one of the most rapidly urbanizing cities in Africa, faced with challenges of squatter settlers. The shelters are, built by the efforts of the squatters who cannot afford to secure legal or formal land or a safe site on which a house can be built (Obiadi, 2017). Informal land developments provide shelter for over $85 \%$ of the population of urban residents in most developing Nations (UNCHS, 1996; Durand-Lasserve, 1997).

The government in Abuja has always confused squatter settlements from the urban poor and as Bello (2009) indicated, the focus has always been on squatter or informal settlements and not on the urban poor, or their inaccessibility of land. This is a wrong approach. This is why when a squatter settlement is redeveloped, what is successfully done is to push the squatters to another location while redistributing their lands among the rich. Squatter settlements develop because there exits some urban poor who desire at least a roof over their heads, but their income and high cost of land have pushed them to where they are, and called home; and where you called, squatter settlements (Bello, 2009).

Generally, as the population and affluence grew, there exists an increase in the demand for land by government, private individuals and corporate bodies. Unfortunately, since the physical overall supply of land within a geographical area is fixed, demand always outstrips supply by a very wide margin, especially in the urban centers. This inevitably brings about the survival of the fittest syndrome. In this struggle, government has the upper hand through the exercise of the power of eminent domain, while individuals and corporate bodies meet their 
land requirements in the open markets. Within the open market, the corporate bodies and the rich individuals usually with higher bargaining power, dominate the transaction; while the urban poor are left with little or no choice but to make do with the crumbs. Consequently, this group of individuals, in most cases, occupies the less desirable areas such as marshy sites, neighborhood adjacent to refuse dumps and where they can find one, they encroach on government lands. The emergent settlement usually evolved as a spatial concentration of poor people in the poor areas of the cities. As expected, these settlements are characterized by infrastructure deficiencies, shanty structures, poor sanitation, urban violence and crime (Plate 2). These composition and characteristics have always made squatter settlement a source of worry and concern to the adjacent neighbours and governments (Bello, 2009).

According to an Abuja Development Control Personnel interviewed, "the Abuja Master Plan indicated that Abuja was designed to be developed in four (4) phases. While all the satellite towns including, Gwagwalada, Kubwa, Nyanya, Karu, Jukwoyi, Chika, Kuchigworo, Pyakassa, Idu, Mpape, Karimu, Gwagwa, Dei-Dei, etc. were designed and zoned for low income families to avoid the sprinkling up of shanty towns at the peripheries. Phase 1 to 4 , among other facilities, were designed to have high, middle and low density residential areas. According to him, there is no area in the Master Plan designated for high, middle and low density areas along major corridors although, high density areas were to be developed closer to the major corridors within walking distance to public transportation. The low density residential areas are mostly occupied by rich and affluence who can afford them. The areas are mostly single family residential and detached. The middle density residential areas are mostly double duplex and low rise apartments, occupied generally by middle income people while the high density areas of the phases, consisting of high rise apartments, multiple story buildings are occupied by low income people" (Obiadi, 2017).

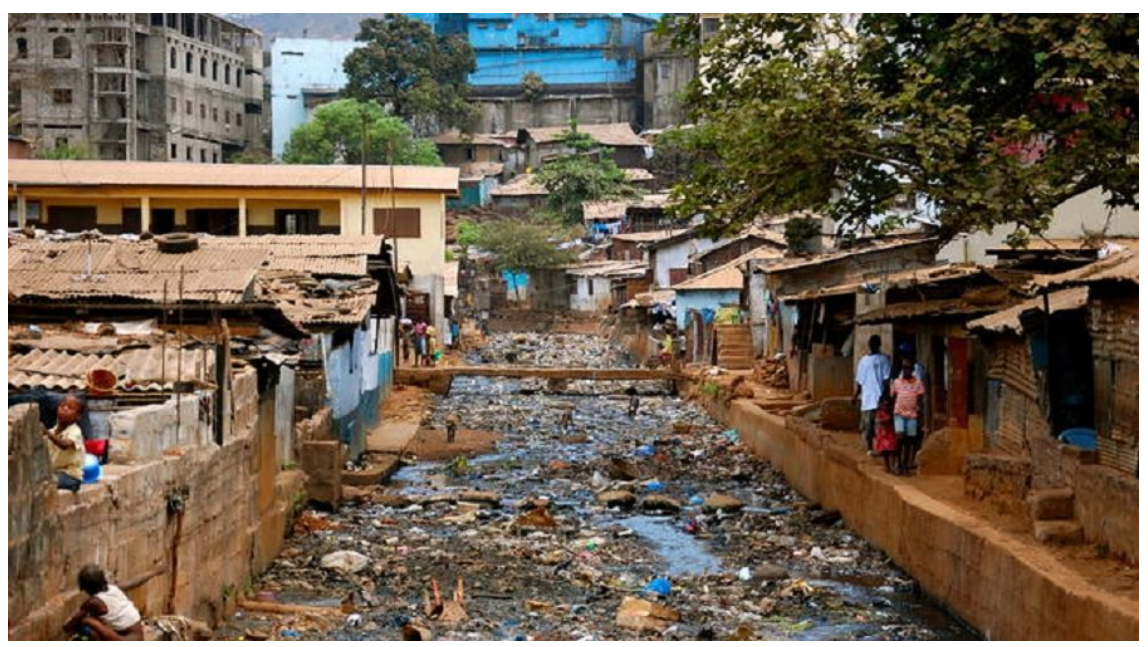

Source: buzznigeria.com (2018).

Plate 2. Abuja slum architecture. 
According to the Abuja Development Control Personnel, "unfortunately, within the high, middle and low density residential areas are pockets of slums, ghettos and outside shelters." Outside shelters are mostly occupied by security men and their family members, servicing the high, middle and low density areas (Plate 1). To emphasize more on this, Abuja City (May 30, 2016) indicated that, the 1979 Master Plan called for Abuja to be developed in four phases. It estimated a population of about 3 million by the year 2010 and a maximum population of 4 million well into the 21st century. Nearly the entire Phase 1 development has been completed and it includes the following: the Central Business District, the Three Arms Zone (presidency, National Assembly and Supreme Court as well as the Maitama, Wuse, Garki and Asokoro residential and business districts. The Phase 1 area of the city is divided into five (5) districts. They are the Central, Asokoro, Garki, Wuse and Maitama. There are also five districts in Phase 2. They are Kado, Durumi, Gudu, Utako and Jabi. And the Phase 3 districts are Mabuchi, Katampe, Wuye and Gwarimpa. There are also five suburban districts, which are Gwagwalada, Kubwa, Nyanya, Karu and Jukwoyi. Along the Airport Road on the approach to Abuja City are satellite towns, namely Lugbe, Chika, Kuchigworo and Pyakassa. Other satellite towns are Idu (the main industrial zone), Mpape, Karimu, Gwagwa, Dei-Dei (housing the International Livestock market).

The Abuja Development Control Personnel further indicated that, each of the districts in phases 1 to 3 has the three residential areas (low, middle and high density). Again, they equally have pockets of informal settlements (Obiadi, 2017). Jibril (2006) indicated that, the initial target for movement from Lagos to Abuja was put at the year 1986. So the initial implementation strategy for the Master Plan envisaged that the workers would be housed in the "Accelerated District" within the Phase I Area of the city's development. This "Accelerated District" was to be developed for low-income workers to prevent the emergence of shanty towns in the periphery of the capital city. It was also to serve as a "model" for testing out the detailed plan concepts. The decision to move the date forward from 1986 to $1982 / 83$ lead to the emergence of number of shanty-towns and squatter settlements occupied by workers and the growing service population in such places as Karu/Nyanya, Karmo and Gwagwa. These settlements developed rapidly and were generally unplanned, overcrowded and lacking basic amenities and infrastructure (Jubril citing Mabogunje in Ayileka \& Kalgo, 2001).

As indicated by Bello (2009), "the harbinger of squatting activities is inaccessibility of land engendered by low income of the urban poor. The end product is the creation of a slum. The effects of slums have been seen from various perspectives; the commonest one being on the deplorable environmental conditions" (Plate 2). The tenants include, most of the Central City workers who could not afford high rents within Central City. According to Bamidele (2010), "most of the workers who cannot afford to live within the city, find their way to the squatter settlements and uncompleted or abandoned buildings within the city 
which punctuated all high-brow areas of the city and many" (Plates 2-11). The people, according to Uji and Okonkwo (2007), "frustrated by the inadequacies and failure of the conventional approaches to provide urban shelter and services to a significantly large enough proportion of the poor in the urban areas of the developing nations, these ever-increasing class of urban populations have to resort to squatting on public or private land, either by invading and forcefully occupying or leasing such land (illegally sub-divided) on which they hurriedly construct (through self-help) their shelters from any available materials using any readily affordable and available technology" as is the case in Abuja (2 to 11).

Urban Poverty, according to Adiukwu (2014), citing Copenhagen resolution (2000), "is strongly associated with high levels of environmental risk. This is largely due to poor quality and overcrowded housing conditions and the inadequacies in provision of water, sanitation, drainage, health care, garbage/waste collection, poor percolation resulting into flood, building on waterways and pollution of land, air, and water (Plate 1 and Plate 3). The concentration of more people in urban areas has brought more pressure on the land space for the production of food, infrastructure, housing, and industrialization. The movement affects the capacity of the environment to cope, as each additional person increases the demand on the infrastructure and the natural system and as a result creating ecological imbalance with adverse environmental penalty in hazards and disaster (Daramola \& Ibem, 2010).

Almost all the major urban areas in the world are witnessing rural to urban migration resulting in urbanization. Sijuwade (2010) indicated that, we have seen that rural-urban migration brings workers to cities that are already burdened with surplus labor. In the process of rushing to urban areas for work, the area's infrastructure including housing, are over stretched, resulting in formal

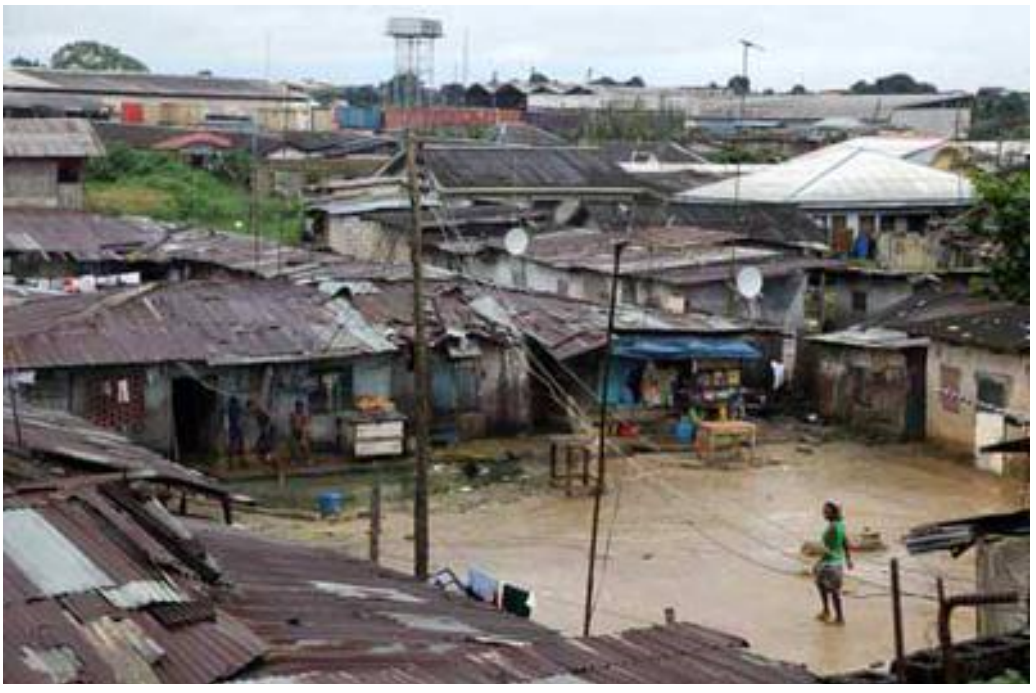

Source: Abuja-ng.com (retrieved June 2016).

Plate 3. Abuja slum. 
settlement areas of major cities being infiltrated by informal settlers (urban dialectics, and dualistic living) and the urban governments cannot cope with the housing supply for their citizens.

\section{All the Abuja Government's Housing Programmes Have Failed}

- The housing provided by the Abuja government failed because of inadequacy of housing and a good access to the central facilities through a corridor of open spaces and lack of economic connectivity (secondary employment).

- The Master Plan was prepared such that land use, infrastructure, housing, transportation, recreation, economic and social services were to be coordinated and inter-related (Olaitan, 2004, citing Abba, 2003), but that was not the case during the implementations.

- Much of our daily experience of the city occurs within the collectively shared public spaces, or the public domain. Not only does the public domain provide for most basic of the city's functions, access, but it also provides for and contains many other functions and activities synonymous with urban life. These are lacking and the problem with Abuja's environmental and urban development.

- Prior to 1973, government activities in public housing had been quite sectional and favored only the working class elites in the society. The poor and low-income were relegated to the background (Olu-Sule, 1988).

- The Abuja government's housing programmes have not worked. The provided Federal Housing units were developed without adequate economic and municipal service facilities as a result, the housing units are not sustainable and also, inadequate for the Abuja steaming population. It equally fails because of the government rush to move government workers from Lagos to Abuja when the government has not provided adequate housing for the workers (Obiadi, 2017).

The government's approaches to solving the problems of the urban poor housing issues in Abuja Federal Capital Territory have not yielded a reliable solution; especially in the area of urban spatial distribution being created by the invasion of the formal by the informal urban dwellers; and to start solving them, this paper explored sustainable spatial integration and retention of the urban poor settlement areas that architecturally bridged the gap (spatial solution) between the urban poor settlements (place of abode) and place of work.

\section{Aim of Study}

This paper aims to document the problems associated with inappropriate implementation of the Abuja Master Plan that resulted in Abuja urbanization and housing inadequacy and proffer solutions to Abuja housing problems.

\section{Research Methodology}

The authors were careful with analytical instrument and tools used. The discip- 
linary area of focus is architecture, or better said, urban design or urban architecture dealing with Abuja: Nigeria's spatial economic turmoil and urban development disarray. This paper investigated and documented the problems associated with inappropriate implementation of the Abuja Master Plan that resulted in Abuja urbanization and housing inadequacy as a result, adopted content base analysis that emphasized the opinions of others. Qualitative research method was used and it investigates the why and how of decision making, not just what, where, when, or "who" (Qualitative Research, 2015). Data was collected from both primary and secondary sources (primary source of data includes, interviews (oral, telephone, television), questionnaires, photographs, etc. Secondary Sources of data includes, literature reviews from journals, previous works, books, etc.). They were collected from all sources including, government establishments, consulting firms, previous research works, case studies, etc. and especially, from the study areas (urban poor settlements), to fully understand and make sense of Abuja's urban poor housing, urbanization and population problems and the associated scarcity of housing.

\section{Findings}

- The Abuja Master Plan was elaborated to put in place, a sustainable urban spatial environment for all groups or classes of activities to be carried out in the Capital Territory.

- The Capital City was planned to be built by the Federal Government in its greater part. The Master Plan actually provided for low-income settlements (housing) areas, to be built by the government and to be occupied by the public servants; the private sector servants did not appear to be properly provided for.

- The development plan and process envisaged the seat of power would move from Lagos to Abuja in 1986, but this time of movement was brought forward to 1982/83; hence the commencement of urbanization stampeded. The most vulnerable, the urban poor had to arrange, on their own, where to live in order to stay close to work place and also reduce rent incidence on their income and that resulted in shanty settlements (in both formal and informal housing areas).

According to an Abuja Development Control Personnel interviewed for this paper in 2017, "the Abuja Master Plan indicated that Abuja was designed to be developed in four (4) phases. While all the satellite towns including, Gwagwalada, Kubwa, Nyanya, Karu, Jukwoyi, Chika, Kuchigworo, Pyakassa, Idu, Mpape, Karimu, Gwagwa, Dei-Dei, etc. were designed and zoned for low income families to avoid the sprinkling up of shanty towns at the peripheries. Phases 1 to 4 , among other facilities, were designed to have high, middle and low density residential areas. According to him, there is no area in the Master Plan designated for high, middle and low density areas along major corridors although, high desity areas were to be developed closer to the major corridors within walking dis- 
tance to public transportation. The low density residential areas are mostly occupied by rich and affluence who can afford them. The areas are mostly single family residential and detached. The middle density residential areas are mostly double duplex and low rise apartments, occupied generally by middle income people while the high density areas of the phases, consisting of high rise apartments, multiple story buildings are occupied by low income people." Within the high, middle and low density residential areas are pockets of slums, ghettos and outside shelters. Outside the gate shelters (Plate 1) are mostly occupied by security men and their family members, servicing the high, middle and low density areas (Abuja Development Control Personnel, 2017).

Jibril (2006) indicated that, the initial target for movement from Lagos to $\mathrm{Ab}$ uja was put in the year 1986. So the initial implementation strategy for the Master Plan envisaged that the workers would be housed in the "Accelerated District" within the Phase I Area of the city's development. This "Accelerated District" was to be developed for low-income workers to prevent the emergence of shanty towns in the periphery of the capital city. It was also to serve as a "model" for testing out the detailed plan concepts. The decision to move the date forward from 1986 to 1982/83 lead to the emergence of number of shanty-towns and squatter settlements occupied by workers and the growing service population in such places as Karu/Nyanya, Karmo and Gwagwa. These settlements developed rapidly and were generally unplanned, overcrowded and lacking basic amenities and infrastructure (Jubril citing Mabogunje in Ayileka \& Kalgo, 2001).

The relocation of Nigeria's Federal Capital from Lagos to Abuja was consistent with the goals and objectives of the Federal Government, but not the desire of the original inhabitants of the Abuja Territory, who found themselves in slums and ghettos. According to Itua (2014), many residents of the slums are victims of heartless demolitions in Abuja. Many of them who are original inhabitants of FCT told Abuja Metro that they are yet to be relocated by the government after their ancestral lands were forcefully taken from them. With the dwindling yearly budget of the FCT, original inhabitants that reside in these slums across the city will have to wait endlessly.

The government has knowingly or unknowingly, separated the urban poor discussions from the problems of the original inhabitants of the Abuja lands, needing resettlement. The government has equally failed to realize that those original inhabitants of the Abuja land are themselves, poor and part of the urban poor classification in Abuja who live in squatter settlements. Government concentrated on relocating the original inhabitants of the Abuja land without solving their economic problems and reviewing their living conditions. According to Obiadi (2017), the original inhabitants were mostly farmers and knew only how to farm and still depended on farming for their daily living.

They live in settlements and the problem the government has been facing is that, most of the settlements are expanding because of influx of people into the settlements and as some of the government officials admitted during the writers 
field work, the inhabitants are outgrowing their current communities (Plates 2-11). On the field, the writers noted that the settlements were overcrowded and the residents expanding the buildings. New buildings as indicated on Plate 4 and Plate 5 were common. Expansions with zink and aluminum products were equally common as shown on Plates 6-11.

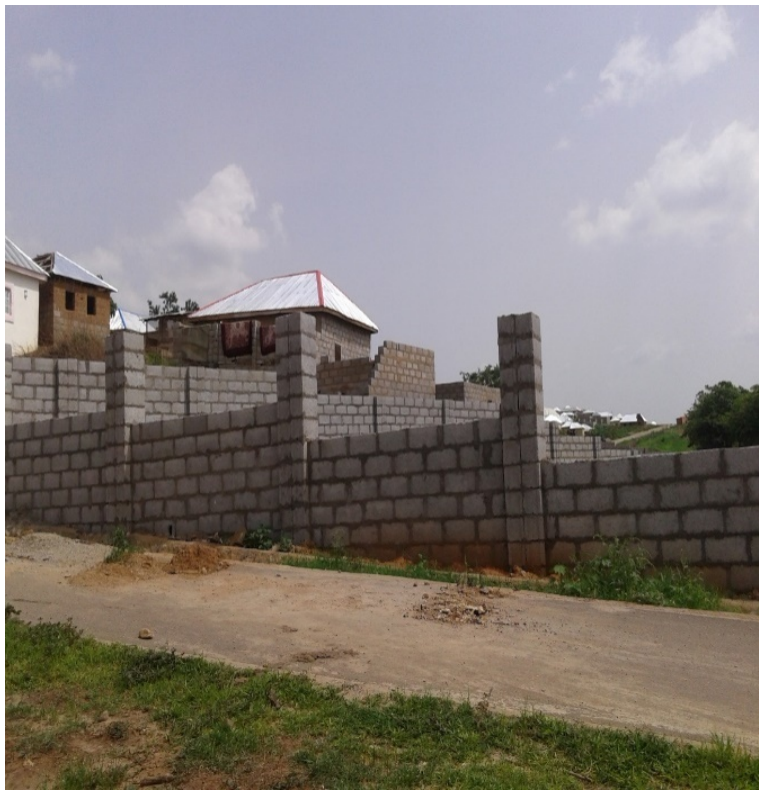

Source: Obiadi (September 2017)

Plate 4. Guzakpe, Abuja settlement expansion.

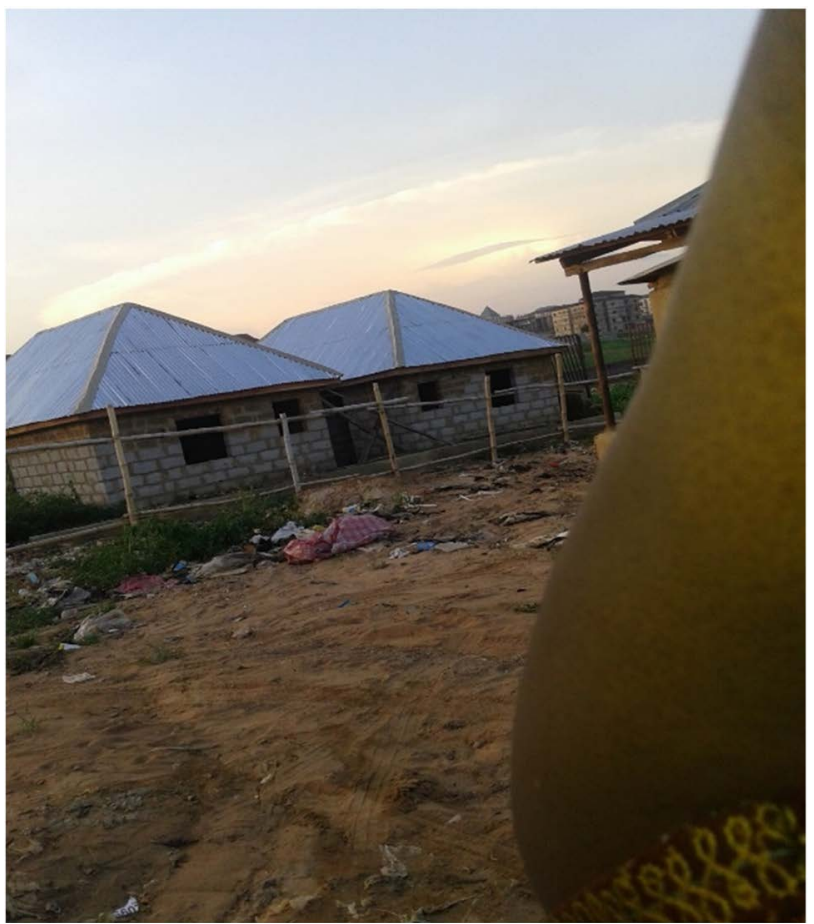

Source: Obiadi (September 2017).

Plate 5. Jabi, Abuja settlement expansion. 
Aduge-Ani (2013) indicated that, the director, department of resettlement and compensation, Federal Capital Development Authority (FCDA), Okechukwu Francis, believes that the best thing to do for the original settlers of Abuja who are caught up in the center of development is to resettle them in a new community, since their present community cannot accommodate all of them. They are fast outgrowing their communities because of the influx of outsiders joining them and answering, "Original inhabitants (settlers)."

The Director, Department of Resettlement and Compensation, Federal Capital Development Authority (FCDA), indicated during a meeting that, the Jabi village settlers have outgrown their current communities and that, government plans to resettle them at Apo, in a much bigger area, but meeting resistance from the community. Apo is still within the Abuja urban center and within a close distance from Jabi communities. During the writers field work, a lot of the people interviewed at the urban poor settlements indicated that the Abuja governments ignored their economic wellbeing. The Abuja governments have failed to address the economic survival of the settlers and their socio-economic needs. "The governments have not reviewed or considered socio-economic programmes that would improve upon the lives of the settlers" was a comment from a Jabi vendor. The settlers whether or not they are the original inhabitants of Abuja land are poor and considered along with the growing population joining them, who cannot afford decent roofs over their heads, are urban poor by any definition and they are in need of decent housing and accommodations.

The Abuja government failed to clearly define and determine who the urban poor in Abuja are and concentrated efforts in finding solutions on how to solve the resettlement problems of the original inhabitants of the Abuja land, that according to the Abuja Master Plan (1979), were to be relocated and clear the Abuja territory of all encumbrances. The Capital City was planned to be built by the Federal Government in its greater part. The Master Plan actually provided for low-income settlements (housing) areas, to be built by the government and to be occupied by the public servants; the private sector servants did not appear to be properly provided for. Policy inconsistencies and changes in the Abuja Master Plan, made the government to abandon its original plan to relocate the settlers before embarking on building Abuja. It was the government's plan to relocate the settlers when development grows into their communities. Developments grew faster than the government had projected, posing challenges to both the government and the settlers. This resulted in the proliferation of informal settlers in formal housing areas of the city and in most cases, the settlers made outside spaces their housing.

The Master Plan put in place plans for the development of satellite tonws that will take the service population away from the Central City and show relationship with the satellite town as indicated in Section 1.10.9, 1.10.10 and 1.10.11. Another area that shows the relationship of the new Capital with the local communities is the establishment of satellite towns which, as earlier pointed out, 
were, among others, to constitute relocation settlements for those villagers who had to vacate their land for the establishment of the FCC. After a thorough analysis of the existing natural condition and the future needs of FCC, Gwagwalada was selected as the first new town to be developed. With a population of about 5000 in 1979, the village was about the largest existing settlement within the FCT. It is located at about 40 kilometers from FCC west of the A2-road (Okonkwo, 2006).

Today, the Gwagwalada-Izom road through Paiko is of much significance. When they are established, it will link the proposed heavy industries of Gwagwalada to Izom's ceramic and mechanized farm projects adjacent to Gwagwalada; currently it diverts some traffic away from the A2-road. The spatial relationship of Gwagwalada with Suleja (though outside FCT) is worthy of note. Suleja's proximity and the early Government policy of encouraging FCT's population movements to Suleja, Gwagwalada and Kwali have helped to stabilize the area (Okonkwo, 2006).

Fundamentally, the idea to establish a series of new satellite towns to supplement the Federal Capital City as pointed out above was actually part of the International Planning Associates (IPA) recommendations on the Implementation of the Master Plan for the City. The need for immediate development of Gwagwalada as the first among the series of the satellite towns thus became apparent with the growing need for administrative attention, distribution of services, facilities and amenities to increasing population of the periphery villages in which local communities expunged by the building process of the new capital resettled (Okonkwo, 2006).

The Draft Regional Plan also recommended that several towns should be designed along the A2-highway as centers for delivery of services to FCT inhabitants. The towns would accommodate resettling Gwari people and attract people from all works of life. Apart from Federal Capital City (FCC), the satellite town of Gwagwalada was planned to become the biggest and most important urban, administrative and cultural center within the Federal Capital Territory (FCT). The functions of the town which are in close connection with the development of the New Federal Capital City include the following

1) To serve as the administrative, commercial and cultural center for the delivery of services to all the settlements and inhabitants of FCT outside the Federal Capital City.

2) To be the agricultural nerve center of the FCT, this will guarantee the supply of food and other allied agricultural goods.

3) To be the center for small, medium and large scale industries within the FCT to supply the inhabitants of FCC with industrial goods which are not produced in FCC itself.

4) To be the center for absorbing surplus immigrants to FCC.

5) To support construction work at the site of the FCC by producing construction materials, accommodating construction workers and providing a 
broad range of services connected with the building of the FCC.

One peculiarity of the town is the link between the traditional village and the added new town. The traditional village of Gwagwalada is a dominant element in the development of the new town. The need to integrate the village with the new town is of the paramount importance. To have done otherwise would have been very costly both in financial and social terms. The Gwagwalada village inhabitants were not resettled in the process. They were not resettled but together with other FCT local communities who relocated from elsewhere were rather integrated into the town through the following measures:

1) The existing village to be allowed to expand into one of the future districts of the new town with its traditional identity.

2) The village to have good access to the central facilities through a corridor of open spaces.

3) The village to be connected to both the residential and the industrial areas of the new town as well as the A2-road.

The town center located at the highest point of the site is being developed as the governmental and cultural center of the new town. The central axis to the traditional Gwagwalada village is part of the town center which serves as the commercial center with some public facilities so as to generate a lively functional connection between the new town and the existing Gwagwalada. In this way, and as expected in other satellite towns, the development of a new town north of the existing Gwagwalada village has necessitated its redevelopment in order to:

1) To improve the standard of life in the villages while simultaneously retaining its traditional characteristics.

2) To integrate the existing village with the proposed satellite town and to serve as a base for the development of the satellite town.

All these development goals were not carried out as proposed. The Central City instead, received more immigrants than expected (Okonkwo, 2006).

Building the Nigerian new capital is an important key event which has imposed a new set of area relationship with a new functional ordering of the local community settlements thereby setting the scene for a totally new phase in the country's urban development history. The Federal Capital Territory (FCT) land mass of $8000 \mathrm{~km}^{2}$ has been an opportunity of life time for Nigeria to not only build a city from the scratch and in line with other modernist piers like Chandigarh and Brasilia but also to evolve a sustainable pattern of managing the relocation effects of the new capital building on the local communities who lived in villages and hamlets (Okonkwo, 2006).

Abuja, on the other hand, is a completely new town, on a site which had very few residents and thus could not be associated with any Nigerian ethnic group. Oil money made it possible to spend millions of naira to speed the building of Abuja, but the full transfer of the seat of government from Lagos only took place in 1992. The new capital is intended to serve "as symbol of Nigeria's aspiration for unity and greatness" as a central, neutral and healthful place with plenty of 
room for urban development (Abuja Master Plan, 1979: p. 27). There are plans for 150,000 residents by 1986, largely civil servants from Lagos and their families, and ultimately three million. Residential districts of from 40,000 to 60,000 are grouped into mini-cities of 100,000 - 250,000 people with some secondary employment in each. High-density areas are placed closer to the transit corridors than low-density areas, but considerable attention has been given to making all sectors of the city easily accessible by motor vehicles. The first housing built was for 20,000 civil servants. As is inevitable in large-scale government projects, there will be far more segregation of housing by income in Abuja than in most Nigerian cities (ECA, 1980). On the whole, capitals continue to be stronger drawing-points than new industrial towns because their size and prosperity provide wider employment opportunities. Abuja was not immuned from this fallout. Plate 2 to Plate 11, clearly show urban poor settlements in the Capital City and surrounding territory and the rate, at which they are growing.

In the field, the writers found formal (well surveyed settlements) and informal housing [urban poor settlements (slums)] characterized by Quick-Fix (make-shift) homes, mostly built with recycled wood, zinc and aluminum products and from

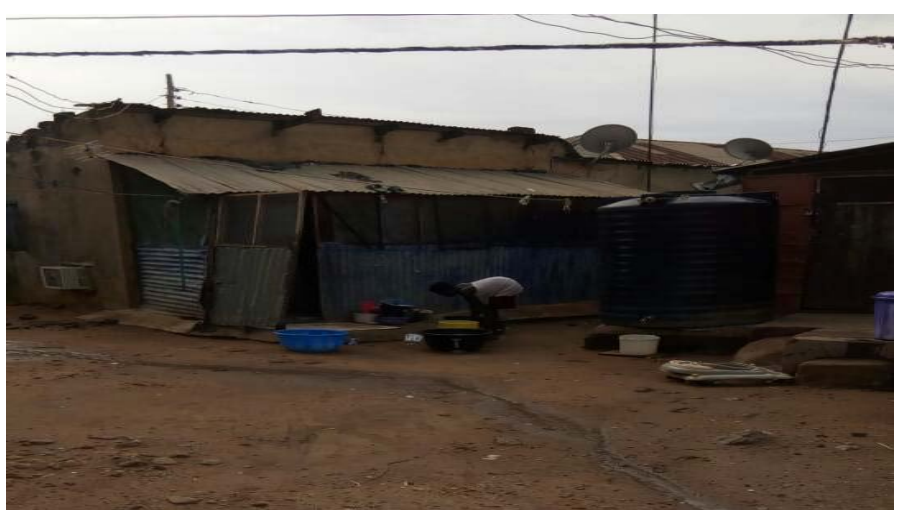

Source: Obiadi (September 2017).

Plate 6. Womba-Apo Village, Abuja urban poor housing.

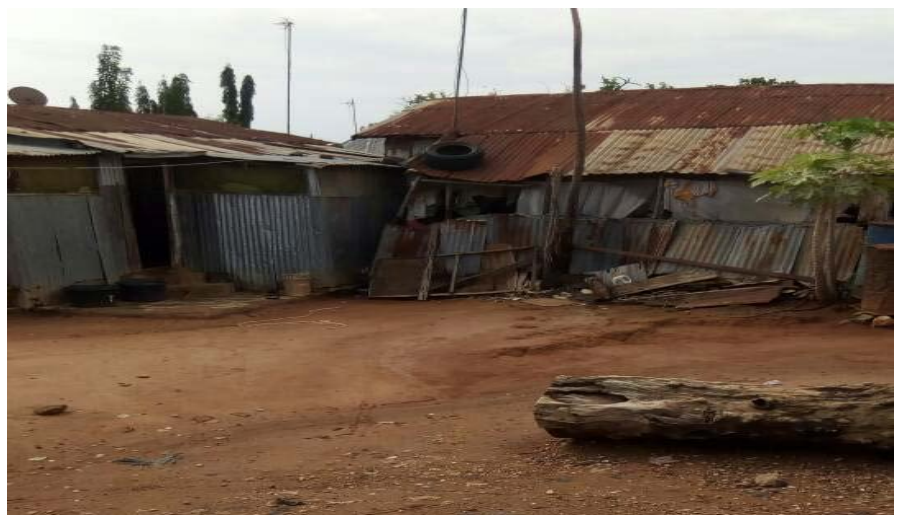

Source: Obiadi (September 2017).

Plate 7. Womba-Apo Village, Abuja urban poor housing. 


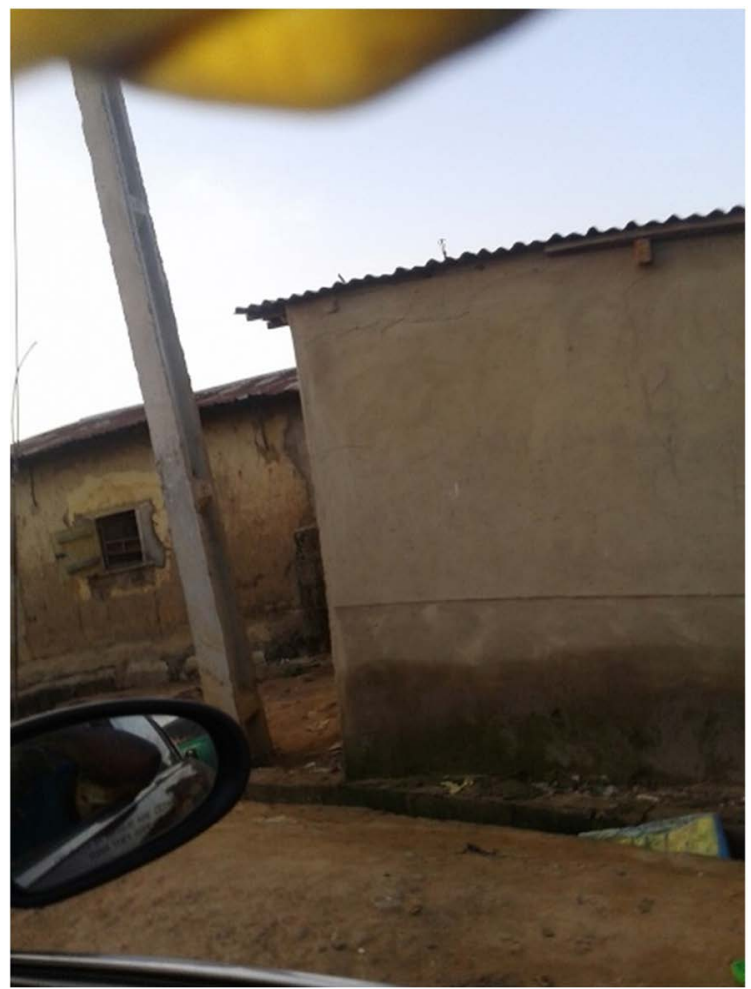

Source: Obiadi (September 2017).

Plate 8. Utako, Abuja settlement area.

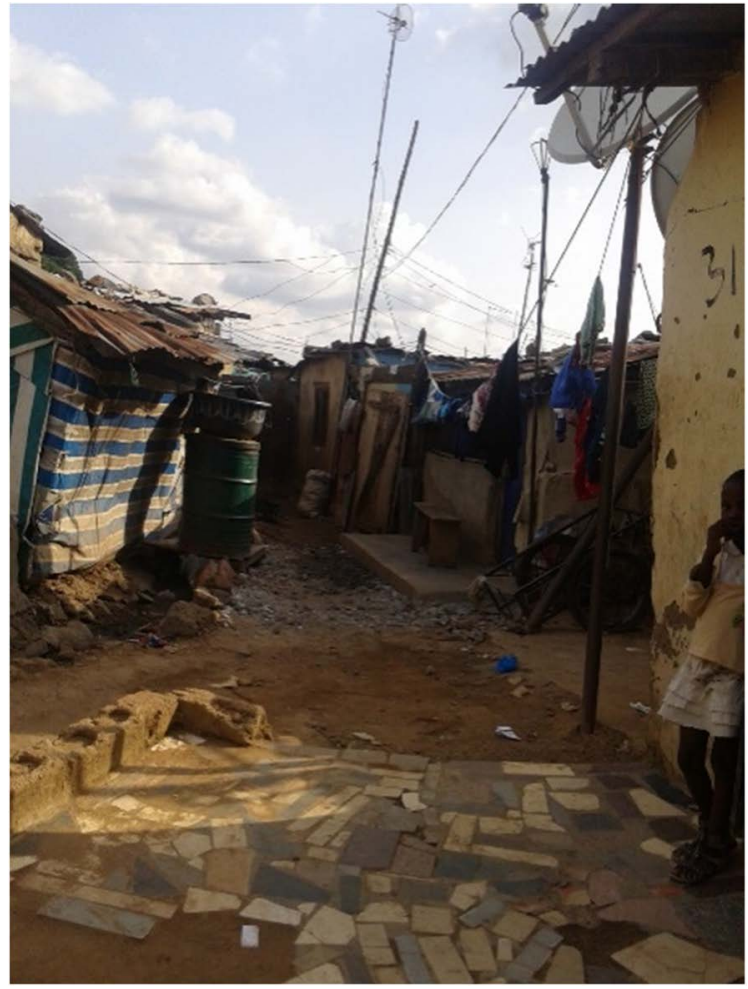

Source: Obiadi (September 2017).

Plate 9. Utako, Abuja settlement area. 


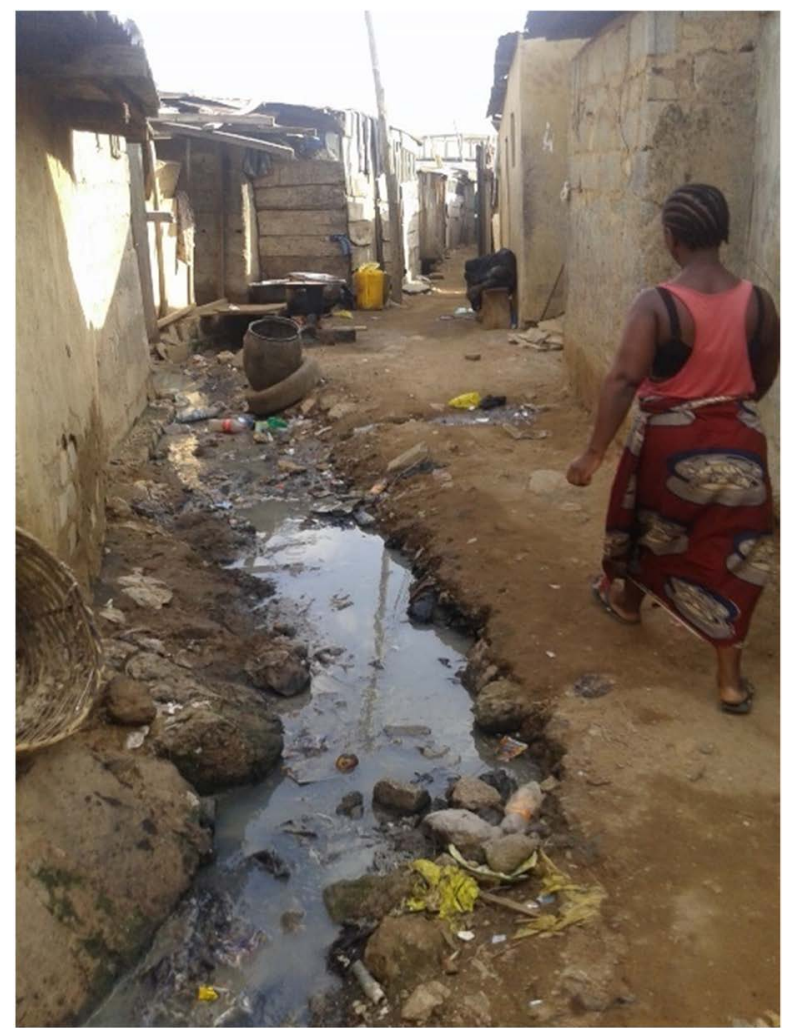

Source: Obiadi (September 2017).

Plate 10. Utako, Abuja settlement area.

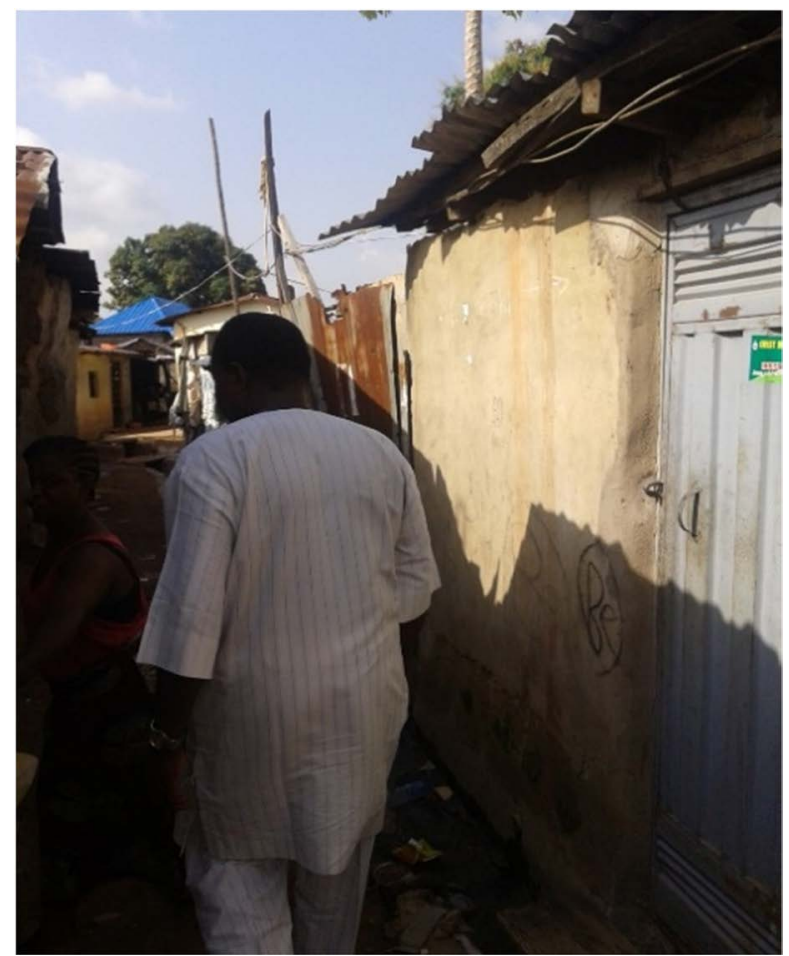

Source: Obiadi (September 2017).

Plate 11. Utako, Abuja settlement area. 
construction sites (Plates 2-11). The settlements have homes in total disrepair; the areas littered with waste and unkempt (even at the middle of formal housing areas). The majority of the settlements have narrow and overflowing dirty gutters that zigzagged around the make-shift homes (Plates 8-11). They lacked infrastructure, but could be linked up with the surrounding Central City infrastructure. Interview with the residents revealed that they lived there because of nearness to places of work, both formal and informal. The areas however, have no strong economic production base of any sort and many of the residents have been living there for many years and would prefer to continue living there.

The Federal Capital Territory was planned, to be developed in phases and to accommodate the expectant growth and developments. The area demarcated as the FCT is predominantly in Gwariland and falls into one of the very few "buffer" zones. It has displayed a high degree of neutrality between the major northern and southern ethnic groups. The development was planned in such a way that no settlements or people affected would become separated from their "kith and kin" or be rendered "homeless" in the sense that a whole ethnic group may regard themselves "homeless" if their entire land were taken away from them and they were asked to go to settle in lands belonging to other ethnic groups (Okonkwo, 2006). This however, is not the case. A lot of the displaced people of Abuja land found themselves in areas without their "kith and kin" and in most part, rendered "homeless" and living in urban poor settlement areas.

The level of development attention in the Abuja Master's Plan layouts presupposed complete relocation of the villagers to larger villages outside the Capital City; these larger villages formed the basis of the Regional Plan recommendation for development of series of satellite towns to support the Capital City, but that, so far, is not the case. The Central City area is littered with informal settlements in the formal residential areas (Obiadi, 2017 citing Okonkwo, 2006).

The new capital residential communities are organized around households sharing daily public services which are within walking distances. Such communities vary in size depending on sharing patterns orientation to transportation facilities, residential density, natural physical boundaries, etc. An examination of urban patterns in existing Nigerian cities supports the importance of permitting such factors to reinforce traditional ties of social, cultural, occupational and administrative groupings in evolving a sense of community which can contribute to residential satisfaction. However, the application of this concept in building the new capital implied a physical expunge of the local communities and complete loss of their identity within the city; the names of the villages are retained but the villagers and their settlements are no longer there. Within residential communities, housing dominants land use as well as the most direct point of contact between the new city and its residents. The housing program for the city was formulated to strike a balance between the improved standards of housing which the public and private sectors wished to provide and the costs the city's residents could afford; but seemingly without strategy to involve those who 
originally inhabited the area because they have been asked to relocate outside the capital city.

Relocation of the local communities was planned in phases and areas. Hitherto Government, under the Federal Capital Ministry, is yet to achieve its relocation plans. Apart from the fact that relocation meant socioeconomic dislocation of the local communities, especially those who fell within the Capital City growth areas, the incomprehensive implementation of the programmes compounded the problems associated with local communities' adjustment in resettlement sites. First-phase relocation involved some 11,000 people while later relocation from the remaining City site involved between 8500 and 17,000 people.

However, the associated selective relocation program which meant the relocation of only those villages displaced by specific development has been compounded by constant influx of migrants and steady expansion of the settlements.

Nevertheless, while the origin of the problematic situation of the local communities whose settlements fell within the Capital City site could be in the non-implementation of the planned relocation programmes, the problem of those local communities outside the Capital City but within the FCT responds to their seemingly non-inclusion in the spatial economic order which has evolved as a result of the building of the new Capital within their Gwariland (Okonkwo, 2006).

The initial Government Policy of housing development through the FCDA made people to expect too much from Government. Even though it wanted to set the pace and encourage people to move into an area that was hitherto least developed in the country and lacking in the most basics of all social amenities. After sufficient confidence was built, government did not see the need to continue with that type of development again and so pulled out in 1991 from large scale housing provisions. It did this at a time when the private sector was yet to produce enough housing stock at affordable rate for the ever growing population of the territory. The consequences are of course acute shortages of housing stock within the city and its immediate environs. The only solution was recourse to squatting solution by people mostly not engaged in the formal sector and therefore not entitled to any form of Government housing provisions. To further compound the problems, the few private developers did not build for low income earners-people mostly engaged in the informal sector. Lack of a well-developed Mortgage Institutions did not give much room for private developers to provide enough housing scheme for low income earners hence squatter development in Abuja (Jibril, 2006).

Furthermore, there are plans for 150,000 residents by 1986, largely civil servants from Lagos and their families, and ultimately three million. Residential districts of from 40,000 to 60,000 are grouped into mini-cities of 100,000 250,000 people with some secondary employment in each. High-density areas are placed closer to the transit corridors than low-density areas, but considerable attention has been given to making all sectors of the city easily accessible by 
motor vehicles. The first housing built was for 20,000 civil servants. As is inevitable in large-scale government projects, there will be far more segregation of housing by income in Abuja than in most Nigerian cities (ECA, 1980).

Based on these conditions, the present authors state that, the Abuja governments have not considered all the housing options, in housing the ever increasing Abuja's population as a result, the Abuja urban poor are found in both formal and informal housing settlements of the city. They live in make shift homes and run their commercial operations to survive.

\section{Recommendation}

The current Abuja settlement patterns (formal and informal) are not integrated in terms of contiguous economic and urban development growth. There is, inexistence, adverse economic inequality and injustice within the Capital City of Abuja and the need for the formal, informal settlements and the Abuja urban actors to be talking, to link the informal and formal settlements together and tie them into the Central City infrastructure.

All over the world, including Nigeria, all the major cities are over populated, faced with inadequate housing, buildings in disrepair, traffic jams, bad roads, pressure on infrastructure, etc. With all these problems, this paper recommends that, connecting to the world class would be farfetched until governments start working on sustainable spatial retention programmes, providing facilities that would create the much needed comfort zones for the people. As indicated in the "Challenges of Abuja" above, all the Abuja government's housing programmes have failed. They failed because of inadequacy of housing and a good access to the central facilities through a corridor of open spaces and lack of economic connectivity (secondary employment). As a result, this paper recommends that, the Abuja government should along with the provision of housing for all, create sustainable job opportunities for the residents. Create opportunities that would economically impact the communities, improve the living conditions of the people by adequacy in infrastructure including, but not limited to, municipal water supply, electricity, affordable city and regional transportation services, security protections, etc. The government needs to be a great motivator by providing the communities with programmes that would rejuvenate hope and confidence in them, economically empower them and emancipate them from adverse hardship.

These could be accomplished through good initiatives, government interventions, cooperative assistance and partnering with the people (privatization). These are possible and attainable through Sustainable Spatial Housing Design for the Urban Poor in Abuja, where one would live and work within a short distance, partake in the ownership of the community, government offices and industries located within the settlements, tourism facilities, trade show facilities, conference centers and other international attractions, located within the areas. 


\section{Conclusion}

The city is a fundamental and universal human creation. It is a unique center for social life as well as individual and collective fulfillment. The frantic, irreversible urban growth that societies throughout the world have experienced over the past few decades has caused a transformation of cities and agglomerations, which rarely correspond to inhabitants' legitimate needs, expectations and aspirations (Lerner, 2003). Various current movements in urban design seek to create sustainable urban environments with long-lasting structures, buildings and a great livability for its inhabitants. The most clearly defined form of walkable urbanism is known as the Charter of New Urbanism. It is an approach for successfully reducing environmental impacts by altering the built environment to create and preserve smart cities that support sustainable transport. Residents in compact urban neighborhoods drive fewer miles and have significantly lower environmental impacts across a range of measures compared with those living in sprawling suburbs (Ewing, 2009).

The Abuja urbanization, spatial economic turmoil and urban development disarray resulted from the poor implementation of the Abuja Master and the use of nonprofessionals in the execution of the Master Plan. That resulted in the dualistic and pluralistic architecture of Abuja, Nigeria.

The government needs to look into sustainable spatial integration and retention (in their current locations) of the urban poor settlements in line with regional/territorial spatial developments that would accommodate the interest of that segment of the communities, rendering essential services to the rich (highbrow areas of the communities). The form and functionality of the project would more or less, not depend on a particular layout pattern because of the configurations of the existing urban poor neighborhoods in Abuja. To embrace spatial integration of the urban poor neighborhoods in Abuja with the Capital City Area, the growth and functionality, the development would not adopt a particular layout pattern, but would be a Dynamic Polynuclear City System (Clay, 1980) that would embrace a combination of systematic gridiron and unsystematic land subdivisions with attractive features and landmarks (city elements).

The government in Abuja, Nigeria could control Abuja's urbanization, homelessness, population growth and their consequences through the adoption of New Urbanism. A theory promotes smart cities by reducing environmental impacts. The adoption of high rise buildings is encouraging. It is a widely accepted fact that the towers and skyscrapers are advantageous in housing accommodation, in urban areas with high population density and decreases the cost of municipal infrastructure. They accommodate more people per unit of area of land when compared with single family buildings and low rise apartments. The assimilation of urban design principle, dealing with the density of the communities, circulation patterns and expansions, open spaces, parks, decongestions of the communities with the use of high rise buildings and row housing would help in 
solving Abuja's urbanization and housing inadequacies.

\section{Conflicts of Interest}

The authors declare no conflicts of interest regarding the publication of this paper.

\section{References}

Abba, A. (2003). Saving the City of the Abuja from Dir, Faeces, Garbage and Disease. In-Depth Analysis, 3, No. 5.

Abuja Master Plan (1979). The Master Plan for Abuja. The New Federal Capital of Nigeria. Lagos, Nigeria: Federal Capital Development Authority (FCDA), State House, Marina.

Adeponle, B. J. (2013). The Integrated City as a Tool for Sustainable Development. Journal of Educational and Social Research, 3, 145-153. https://doi.org/10.5901/jesr.2013.v3n5p145

Adiukwu, F. O. (2014). Prospects and Challenges of Informal Settlements and Urban Upgrading in Abuja. International Journal of Innovation and Scientific Research, 11, $420-426$

Aduge-Ani, D. (2013). The City Centre of the Nation's Capital Abuja Is Surrounded by Growing Slums and Ghetto Settlements. Leadership Weekend. http://leadership.ng/news/091113/welcome-abuja-city-slums-and-ghettos

Ayileka, O., \& Kalgo, M. S. U. (2001). The Review of Abuja Master Plan. Abuja: Proceedings of an International Workshop for the Review of the Abuja Master Plan, Ministry of the Federal Capital Territory.

Bamidele, G. (2010). Abuja: The Vexed Problem of Housing. News Diary Online.

Bell, M. (1981). Modern Sector Employment and Urban Social Change: A Case Study from Gaborne, Botswana. Canadian Journal of African Studies, 15, 259-276. https://doi.org/10.1080/00083968.1981.10803976

Bello, M. O. (2009). Squatter Settlement, Accessibility of Land and the Urban Poor. FIG Working Week 2009. Surveyors Key Role in Accelerated Development Eilat, Israel.

Clay, G. (1980). Close-Up. How to Read the American City. The University of Chicago Press, Chicago and London, 34, 130-131.

Daramola, A., \& Ibem, I. (2010). Urban Environmental Problems in Nigeria: Implications for Sustainable Development.

Dickenson, J. P., Clarke, C. G., Gould, W. T. S., Hodgkiss, A. G., Prothero, R. M., Siddle, D. J., Smith, C T., \& Thomas-Hope, E. M. (1983). A Geography of the Third World. London and New York: Methuen.

Durand-Lasserve, A. (1997). Land for Housing the Poor in African Cities. Are Neo-Customary Processes and Effective Alternative to Formal Systems? Paris: SEDET Centre National de la Recherche Scientifique Université Denis Diderot. http://siteresources.worldbank.org/INTURBANDEVELOPMENT/Resources/336387-1 268963780932/6881414-1268963797099/durand-lasserve.pdf https://doi.org/10.3362/9781780446325.012

ECA (1980). Report on the Demographic Survey of Households, Housing and Living Conditions in Lagos, UN Economic Commission for Africa, Addis Ababa.

Ewing, R. (2009). Growing Cooler-The Evidence on Urban Development and Climate 


\section{Change.}

Gutkind, E. A. (1967). Urban Development in Southern Europe: Spain and Portugal(Vol. III). New York: The Free Press.

Howard, E. (1898). Garden Cities of Tomorrow. http://en.wikipedia.org/wiki/file_Garden_City_Concept_by_Howard.jpg

Hoyle, B. S. (1978). African Socialism and Urban Development: The Relocation of the Tanzanian Capital. In J. S. Oguntoyinbo et al. (Ed.), International Geography (Vol. 2). Lagos: Regional Conference of the International Geographic Union.

Itua, F. (2014). Abuja Metro Cover, Specials. Inside Abuja Slums: How Nigeria Languished amid Plenty.

Jibril, I. U. (2006). Resettlement Issues, Squatter Settlements and Problems of Land Administration in Abuja, Nigerian's Federal Capital (pp. 1-13). Accra, Ghana: Promoting Land Administration and Good Governance.

Lerner, J. (2003). Keynote Address to IUD.

Mlia, J. N. (1975). Malawi's New Capital City: A Regional Planning Perspective. Pan-African Journal, 8, 387-401.

Nwafor, J. C. (1980). The Relocation of Nigeria's Federal Capital: A Device for Greater Territorial Integration and National Unity. GeoJournal, 4, 359-336.

Obiadi, B. N. (2017). Evolving Modalities for Sustainable Spatial Housing Design for the Urban Poor in the Federal Capital Territory, Abuja, Nigeria. Enug State, Nigeria: University of Nigeria.

Obiadi, B. N. (2018). Conventional Approaches to Providing Shelter and Services in Abuja, Nigeria: A Case of Urban Poor Housing Provisions. International Journal of Scientific \& Technology Research, 9, 965-993.

Okonkwo, M. M. (2006). The Building of a New Capital and its Local Communities: Abuja Federal Capital City in Focus. Public Space as an Element in the Shaping of Local Societes (pp. 68-85). Urbanistyka: Miedzyuczelniane Zeszyty Naukowe.

Okonkwo, M. M. (2013). Urban Development in Nigeria-A Post-SAP Period Pattern. Nigeria: Forth Dimension Publishing Co., Ltd.

Olaitan, D. T. (2004). Sustainability and City Development. A Critique of the Implementation of the Abuja Master Plan. Akoka-Yaba, Nigeria: University of Lagos.

Olu-Sule, R. A. (1988). Housing and Environmental Planning: A Synopsis on Urban Development in Nigeria (pp. 114-115). Calabar: Wusen Press Ltd.

Peil, M., \& Sada, P. O. (1984). African Urban Society. John Wiley \& Sons, Chichester.

Pitte, J. R. (1977). article title. Nouakchott: Capitale de la Mauritanie. Dept. de Geographie de L'Universite de Paris-Sorbonne, Paris.

Potts, D. (1984). The Development of Malawi's New Capital at Lilongwe: A Comparison with Other New African Capitals. Comparative Urban Research, 10, 42-56.

Qualitative Research (2015).

http://en.wikipedia.org/wiki/Qualitative_research

Sijuwade, P. O. (2010). The Economic Implications of Rapid Urban Growth in the Third World Countries. The Anthropologist, 12, 79-85. https://doi.org/10.1080/09720073.2010.11891135

Uji, Z. A. and Okonkwo, M. M. (2007). Housing the Urban Poor, User Involvement in the Production Process (pp. 11-17). Enugu, Nigeria: EDPCA Publications.

Uloko, C. O. (2005). The Abuja Master Plan: The Need for a Better and Sustainable Out- 
B. N. Obiadi et al.

look in International Circles. In Built Environment Audit. Lagos: Nigerian Institute of Architects.

UNCHS/HABITAT (1996). An Urbanizing World. Global Report on Human Settlements. London: Oxford University Press. 